\title{
Jordan Education Reform for the Knowledge Economy Support Project - A Case Study
}

\author{
Dr. "Mohammad Ali” Akour \\ Assistant Professor of Information Systems, IS Department \\ Faculty of Information Technology, Al -albayt University, Mafrq, Jordan \\ E-mail: ama@aabu.edu.jo \\ Dr. Rifat O. Shannak \\ Associate Professor of MIS, Chairman of MIS Department \\ Faculty of Business, University of Jordan, Amman, Jordan \\ E-mail: rshannak@ju.edu.jo
}

Received: July 7, 2012

Accepted: July 26, 2012 Published: October 1, 2012

doi:10.5296/jmr.v4i4.2067

URL: http://dx.doi.org/10.5296/jmr.v4i4.2067

\begin{abstract}
This paper evaluates the Government of Jordan Education Reform for the Knowledge Economy program's (ERfKE) Support Project (ESP); Youth, Technology, and Careers (YTC) component. ERfKE was a five-year program (2004- 2009) and considered one of the most ambitious education reform programs in the Middle East with a financial plan of \$380 million dollars. To support ERfKE program, the United States Agency for International Development (USAID) additionally provided approximately $\$ 31.5$ million through its created ERfKE Support Project (ESP). The ESP three major components were: Early Childhood Education (ECE) and Youth, Technology, and Careers (YTC) and the Shorouq initiative supporting South Jordan. The overall performance of the YTC component was certainly encouraging.

Keywords: Information and Communication Technology (ICT), Knowledge Economy (KE), Management and Information Stream (MIS), Education Reform for the Knowledge Economy (ERfKE)
\end{abstract}




\section{Introduction}

Because of the conspicuous global increasing acceptance of Information and Communication Technology in Education (ICTE) as a valuable apparatus for economical and social developments, countries around the world are becoming more and more conscientious of the significance of expanding access to ICT to their societies. In line with this paradigm, in early 2001, His Majesty King Abdullah II of Jordan led the charge to develop Jordan as a knowledge-based economy and called for the reform of the education system in Jordan to become a regional information technology (IT) hub and an active player in the global economy AED (2008).

"We have followed a path that will allow the technological revolution to harness our available talent into productive sectors that can fuel and sustain economic growth." (His Majesty King Abdullah II of Jordan at the World Economic Forum

Davos, Switzerland, January 31, 2000 (as cited in EHKJW (2000))

Consequently, in July 2003, the Government of Jordan (GOJ) launched the Education Reform for the Knowledge Economy (ERfKE) program to focus on the future human capacity needs of Jordan by integrating information technology in education system (e.g., professional training and service delivery). This five-year program is considered one of the most ambitious education reform programs in the Middle East with a financial plan of \$380 million supported by the World Bank, U.S. Agency for International Development (USAID), and other donors (USAID/Jordan, 2006; World Bank, 2009).

Before ERfKE 2003, the majority Jordanian schools had virtually no access to computers and the internet. Those who had few computers shared them by all students and teachers in a school thus limiting their access per user to as little as five minutes each Intel Corporation (2006).

To support ERfKE program, the USAID additionally provided approximately $\$ 31.5$ million between 2004 and 2009 through its created ERfKE Support Project (ESP) that was implemented by the Academy for Educational Development (AED). The goal of ESP was to provide an integrated set of support and capacity-building activities that supported the Jordanian Ministry of Education's ERfKE initiative through three major components: Early Childhood Education (ECE) and Youth, Technology, and Careers (YTC) and the Shorouq initiative supporting South Jordan. The following are the YTC component's six objectives World Bank (2000):

1. Effective enhancement of the MIS curriculum

2. MIS in-service teacher training/professional development

3. Promotion of school-to-career programs in education

4. Support of education technology use and integration in schools

5. Construction of effective technology infrastructure

6. Development of standards and quality criteria 
Because of the vast amount of information related to the ESP's three components and the limited space allowed for this paper, the focus of this paper will be on objectives $1 \& 2$ of the YTC component.

Examination of such ambitious undertaken is imperative to the scientific community, donors, decision makers in Jordan, and decision makers in other countries who desire to replicate such ambitious undertaken. The prospect to repeat and improve on successful project will not accurately occur until a pragmatic analysis of the project is done and the knowledge accrued from the analysis is widely documented and shared.

\section{Methodology}

To obtain details about ESP, a face-to-face interview was conducted with ESP's staff, secondary data obtained from the USAID office in Jordan, and internet information was reviewed. Additionally, two focus groups consisted of nineteen public teachers and schools principals enrolled in an international Master Degree Program in Information and Communication Technology in Education and eighteen recent MI Stream high school graduates that were enrolled in a bachelor degree in Management Information Systems were observed and interviewed.

\section{Background Analysis}

After World War I and the ending of the Ottoman Empire, the United Kingdom ruled a large part of the Middle East. The United Kingdom detached a partially independent state of Transjordan from Palestine in the beginning of 1920s. Transjordan attained its independence in 1946 and 1950 was named the Hashemite Kingdom of Jordan. The country's long-time ruler was King Hussein (1953-99). After his death in 1999, his son King Abdallah II assumed the throne.

Comparatively, Jordan is a new and a small country with a total area of $89,300 \mathrm{sq} \mathrm{km}$, located in the Middle East and has a critical geographic position; boarders with Iraq, Israel, Syria, and Saudi Arabia. With approximately 80 percent of the land desert and water in short supply Jordan is poor in natural resources and lacks a well-developed industrial base. As a result of the influx of refugees resulting from the 1991 Gulf War and the 2003 invasion of Iraq, the population of Jordan rapidly expanded with estimates of 6.34 million as of July 2009 compared to estimates of 3.45 million as of early 1990, of which more than 40 percent are 15 years of age or less. Jordanians are mostly Muslim and Christians consist of approximately six percent of the population holding influential 20 percent of the seats in the parliament. These factors influenced the unemployment rate to be very high. Because of its critical geographic position, reliance on the trade with neighboring countries, and dependence on remittances from Jordanians working in neighboring Gulf countries, its economy is easily affected by the economies and political circumstances in surrounding countries. For example, when the oil economy of the neighboring Gulf countries prospered in the 1970s, Jordan economy strongly prospered too by remittances from Jordanians employed in the Gulf countries, financial assistance from the Gulf countries, and trade the with countries in the region. However, after the oil economy of the neighboring Gulf countries weakened and 
subsequent regional recession, Jordan economy weakened too by mid-1980s resulting from cash-flow problems in the face of declining neighboring Gulf countries assistance. Another example is when the Gulf crisis in 1990-1991 occurred, Jordan economy was adversely affected by low of foreign investors and tourism confidence (AED, 2008; Encyclopedia Britannica, 2009; NRHKJ, 2004; DoS, 2007; UIS, 2007).

Despite these complex challenges, Jordan currently has many comparative advantages within the region including its highly educated population (over 90 percent literacy rate), remarkable historical sites for international tourists attractions, solid and dynamic leadership and government that are committed for pace and open for changes, and a strong support from the United States of America-USAID.

Over the past five decades, the USAID Mission to Jordan has been a key factor in Jordan's development with a total economic assistance provided since 1951 now exceeds $\$ 4.1$ billion. Recently, USAID has drastically increased the total Economic Support Funds that it gives to the Jordan. In Fiscal Year 2009, USAID/Jordan's education assistance to Jordan will reached nearly $\$ 80$ million and the total of the Education portfolio over the 2009-2013 Strategy period is $\$ 240$ million making it one of the highest levels of USAID assistance per capita in the world (USAID/Jordan, 2010). According to the USAID/Jordan Strategy 2004-2009; Gateway to the Future (2003), in the past few years, Jordan has been a major beneficiary of foreign aid from USA and principal European and Asian donors because of its commitment to pace. In 2002, Jordan received $\$ 470$ million in grant assistance from USA (60 percent), European Union (23 percent), Japan ( 7 percent), Germany (4 percent), Spain (2 percent), Saudi Arabia (2 percent), and Canada, Norway, the World Bank, the Arab Fund and the Islamic Development Bank combined (2 percent). The aim of the USAID assistance for economic and social development in Jordan is to support regional stability and sustain U.S. political leadership in the Middle East region.

In attempt to cope with the aforementioned complex challenges, GOJ has undertaken an aggressive economic reform programs in cooperation with the IMF, USAID and the World Bank. In year 2000 Jordan joined the World Trade Organization, and in year 2001 started to participate in the European Free Trade Association. Recently, Jordan invested heavily on the development of knowledge-based industries mainly in ICT sector because it requires least amount of physical material inputs, of which Jordan is lacking and costly to import, and relies mainly on human capital. Perhaps, the development of a knowledge-based economy with competitive employees' skills relies mainly on the accomplishment of its education reform efforts. The education reform efforts are particularly vital to Jordan since over $40 \%$ of its population is below the age of 15 (AED, 2008; World Bank, 2000).

According to the Ministry of Education; The Development of Education National Report of the Hashemite Kingdom of Jordan (2004), the term 'Knowledge Economy' was launched by the Government of Jordan in 2003, referring to the transformation benefits of economic and social initiatives by the applications of ICTs:

Knowledge Economy is the economy which involves the acquisition, sharing, using, employing, inventing, and producing of knowledge with the aim of improving the quality of 
all aspects of life, by benefiting from a rich information service, advanced technological applications, utilizing the human mind as a rich knowledge capital, and employing scientific research so as to bring about strategic changes in the economic environment, in order to face the challenges of globalization, ICT, globalization of knowledge, and sustainable development.

The basic, integrated, and coherent elements set of Knowledge Economy include supportive societal infrastructure, readiness of knowledge workers and knowledge makers, broadband electronic connectivity, easy access to the internet, and disseminate the culture of a learning society in all societal institutions. Knowledge Economy has key characteristics and functions including: high quality aiming at distinction, dense with knowledge, readiness of workforce, pursues continual learning and training, flexible and responds quickly to changing needs, open to the world and competitive, employs an effective system of marketing, shifts economic activity from commodity production to knowledge service production, invests renewed energy, increases the income of competence knowledge makers, assists in building and employing ICT systems effectively, stimulates research and development, and within Knowledge Economy the work contracts are more flexible, temporary, and task related NRHKJ (2004).

The characteristics of qualified human resources required by Knowledge Economy include: advanced and continual education and training, a high level of empowerment, dedication for professional development and continual self learning, strong communications and problems solving skills, creative, decisions makers, flexible and able to move from one profession to another, and successful computer skills. In line with the needs of Knowledge Economy, ERfKE initiative tag on for the application of ICTs to accelerate learning, strengthen pedagogy, increase access to the latest information, implement e-learning components of the curriculum, strengthen links between schools and the world of work, improve the physical environment in schools and promote early childhood education, upgrade teacher training and skills NRHKJ (2004).

In July 2003, the GOJ launched a third-phase \$380 million Education Reform for the Knowledge Economy (ERfKE) initiative to address the future human capacity needs of Jordan. The goal of the GOJ's 5-year ERfKE program was to improve early childhood, primary, and secondary education throughout Jordan's public education system utilizing, when feasible, information technology as a key mode of professional training and service delivery. The heart of ESP was to enhance the access, quality, and relevance of education for children and youth in Jordan. ESP partnered with Ministry of Education, Intel Corporation, and Microsoft Corporation carried out pilot activities testing strategies to improve access to ICTs in schools and to better prepare young people for the world of work (AED, 2008; USAID/Jordan, 2009); USAID/Jordan, 2006).

The ERfKE Support Project (ESP) was a USAID-funded project in support of the Government of Jordan Education Reform for a Knowledge Economy program. ESP began officially on July 1, 2004. USAID provided approximately \$31.5 million between 2004 and 2008 through its ERfKE Support Project (ESP). The Academy for Educational Development 
(AED) manages the project under the Educational Quality Improvement Program 2 (EQUIP2) cooperative assistance mechanism and implemented the project in partnership with the American Institute for Research (AIR). The goal of ESP was to provide an integrated set of support and capacity-building activities that supported the Jordanian Ministry of Education's ERfKE initiative through three major components: (1) Early Childhood Education (ECE), and (2) Youth, Technology, and Careers (YTC), and (3) the Shorouq initiative supporting South Jordan. Each of these components was formed to support the idea of knowledge economy. Because of the vast amount of information related to the ESP three components and the limited space allowed for this paper, the focus of this paper will be on the YTC component objectives 1 and 2 (AED, 2008); USAID/Jordan, 2006); UIS, 2007)

\section{ESP/YTC Component}

Eyango \& Al-Shaer (2003) described the operating guidelines for USAID program design which echo many criticisms of the Jordanian national education system. The following criticisms depict Jordan's education sector:

- Poor quality: relying on rote memorization methods instead of critical thinking; the result of TIMMS study 1999 indicate that Jordanians students' scores of mathematics and science were at the bottom.

- Lack of relevance of education to meet workforce needs.

- $\quad$ Limited access to early childhood education (ECE).

- Poorly trained teachers.

These challenges along with the previous ones have shaped USAID/Jordan's education program: According to AED (2008);

YTC supports Component 2 of ERfKE, which is by far the largest and most complex component of the World Bank-financed reform. It encompasses curriculum and textbooks development, teacher professional development, examinations and testing, technology infrastructure and education technology, school capacity building/school improvement initiatives, school-to-career programs, and innovations funds and grants among its programs, projects, and activities.

The purpose of component 2 was to improve the curriculum for the new Management and Information Stream (MIS) in grades 11 and 12, to better prepare youth for the workforce, integrate the use of information and communication technologies (ICTs) into teaching and learning in the MIS program, develop e-Learning curriculum elements to support teaching and learning, strengthen teacher training capacity for the MIS program, help train MIS teachers, and develop a pilot school-to-work (STW) transition program in grades nine through 12. The following are the YTC component's six objectives of which objectives 1 and 2 will be the focus of this paper due to the limited space allowed for this paper (AED, 2008):

7. Effective enhancement of the MIS curriculum

8. MIS in-service teacher training/professional development 
9. Promotion of school-to-career programs in education

10. Support of education technology use and integration in schools

11. Construction of effective technology infrastructure

12. Development of standards and quality criteria

The YTC component was originally carried out through a partnership between AED and Research Triangle Institute (RTI), with the RTI being responsible for the school-to-career program. YTC program was merged in 2005 into one component executed by AED, with a total staff of 15 people responsible for both YTC component and ESP network infrastructure. School-to-career program was later subcontracted to Save the Children. ESP supported the MOE development of a data repository system of which in turn informed the design and development of web applications that are an integral part of YTC (AED, 2008). Table 1 shows the ESP/YTC Component Deliverables (2004-2008) as follows:

Table1. ESP/YTC Component Deliverables 2004-2008

\begin{tabular}{|c|c|c|}
\hline Component & Deliverable & \\
\hline MIS & $\begin{array}{l}\text { Textbook review/revision } \\
\text { MIS matrix for integration/theme } \\
\text { development } \\
\text { Teachers' guides } \\
\text { Dokkaneh Teachers' Guide }\end{array}$ & $\begin{array}{l}\text { MIS-Online (Grade 11) } \\
\text { Economics integration } \\
\text { Visual Basic.NET migration } \\
\text { MIS Learning Resource Library }\end{array}$ \\
\hline $\begin{array}{l}\text { Professional } \\
\text { Development }\end{array}$ & $\begin{array}{l}\text { Emergency teacher training } \\
\text { Instructional strategies } \\
\text { New teacher orientation } \\
\text { School-based training } \\
\text { Instructional systems design } \\
\text { National School-Based } \\
\text { Professional } \\
\text { Development Conference }\end{array}$ & $\begin{array}{l}\text { Subject-specific training } \\
\text { MIS co-planning / co-teaching } \\
\text { Communities of practice / } \\
\text { champions } \\
\text { Assistance with School } \\
\text { Development Unit } \\
\text { training for MOE }\end{array}$ \\
\hline $\begin{array}{l}\text { Teacher } \\
\text { Standards }\end{array}$ & $\begin{array}{l}\text { Competency work with Dr. } \\
\text { Al-Noaimi } \\
\text { Teacher standards - comments } \\
\text { and inputs } \\
\text { MIS Domain } 3 \text { subcompetencies/ } \\
\text { standards developed } \\
\text { Teacher portfolio / standards } \\
\text { tracking application developed } \\
\text { Pilot conducted }\end{array}$ & $\begin{array}{l}\text { Suggestions for modification } \\
\text { submitted to } \\
\text { the Ministry for review } \\
\text { (comments with } \\
\text { Dr. Ayasara) } \\
\text { Results of pilot published } \\
\text { /changes } \\
\text { MIS learning environment } \\
\text { standards (MIS }\end{array}$ \\
\hline
\end{tabular}




\begin{tabular}{|c|c|c|}
\hline & & $\begin{array}{l}\text { and PD Centers) } \\
\text { Contribution to SDU school } \\
\text { performance } \\
\text { benchmarking } \\
\text { self-assessment }\end{array}$ \\
\hline $\begin{array}{l}\text { School-to- } \\
\text { Career }\end{array}$ & $\begin{array}{l}\text { RTI program launched } \\
\text { Teacher internships } \\
\text { School-to-Career Strategy / AED } \\
\text { Community-youth mapping, } \\
\text { career } \\
\text { pathways } \\
\text { internships-INJAZ counseling, } \\
\text { support } \\
\text { Project-based learning (Buck } \\
\text { Institute) } \\
\text { Save the Children involvement }\end{array}$ & $\begin{array}{l}\text { Career Pathways counseling } \\
\text { Mapping community assets } \\
\text { Internships } \\
\text { STC Rooms piloted } \\
\text { Extension of pilot }\end{array}$ \\
\hline Technology & $\begin{array}{l}\text { Discovery School Support / } 2 \\
\text { pilots } \\
\text { COW pilot }-4 \text { schools } \\
\text { School Technology Committees } \\
\text { (Discovery School - } 2 \text { pilots) } \\
\text { Hashem Center } \\
\text { Wireless in Discovery Schools }\end{array}$ & $\begin{array}{l}\text { AD/SMS Servers } \\
\text { Support to JEI/NetCorps } \\
\text { Support to World Links - Jordan } \\
\text { Shift in technology/school } \\
\text { connectivity } \\
\text { emphasis to Shorouq }\end{array}$ \\
\hline
\end{tabular}

Source: AED (2008)

\section{Results and Lessons Learned}

The following is a summary description of YTC component's two objectives achievement based on the FINAL REPORT: EQUIP2/Jordan Education Reform for the Knowledge Economy (ERfKE) Support Project (ESP) as follows (AED, 2008).

\section{Objective 1: Effective enhancement of the MIS curriculum}

To improve the MIS curriculum, ESP pursued to: 1) join the MOE to revise the textbooks published in Year One of the program; 2) prepare quality teachers' guides for the six MIS subjects; 3) develop a blended, project-based online learning program (MIS); and 4) develop learning resource libraries, applications such as Dokkaneh (e-commerce web application), glossaries, and an online student portfolio to enrich the MIS program (AED, 2008).

According to AED (2008), the E-Learning Curriculum Elements comprises of ICT-based learning modules that will support the teaching and learning of the MIS content by using a mix of technologies to accelerate learning, stimulate student critical thinking skills, and 
provide a consistent pedagogical approach and high quality instructional content for all teachers and students in the MIS program. MIS consisted of six subjects: Basics of Management, Management Information Systems, Computerized Accounting, E-commerce, Programming, and Business Statistics. The first three subjects were mandatory and the last three were optional.

The MIS-Online program final deliverables prepared for presentation to the technical committee in September and October 2008. While ESP conducted its own independent evaluation of the MIS-Online program, an outside assessment of the program was also conducted by the National Center for Human Resource Development (NCHRD). Results indicate general satisfaction among teachers and students with the project-based learning, collaborative co-teaching/co-planning, and the overall orientation and skill development of the students. MIS curriculum outcomes learned better by the MIS-Online students than their non-MIS-Online peers. MIS-Online students reported having a better overall understanding of business. Furthermore, the learning curve has been steep for transdisciplinary, project-based, blended learning. A significant capacity building resulted from the project for the MOE and for the SMEs working with the content developer, JAID. The project has also resulted in advancing the knowledge of JAID itself about blended e-learning and the management of these types of instructional initiatives (AED, 2008; NCHRD, 2008).

At the beginning, the MOE MIS stream reached 150 secondary schools, about 450 teachers, and 14,000 students. At the end of ERfKE I, the Ministry of Education markedly improved its capacity to deliver the MIS stream to 293 schools by 800 teachers serving approximately 27,000 students. Summary of lessons learned from objective 1 (AED, 2008) :

1. Transdisciplinary incorporation is essential for business and IT students.

2. The Jordan Education Initiative (JEI) stimulated model for design and development needs revision.

3. To develop quality learning resources more effectively, the MOE has to develop archives of photos, icons, graphics, etc. along with other primary resources.

4. To enable rapid development and quicker testing of e-curricula, the MOE needs more streamlined public-private partnerships.

5. The whole curriculum ought to be remapped across all subjects to attain unity in realizing the main understandings needed in business and IT education.

6. MIS-Online shouldn't be considered a supplemental activity, instead it should be considered as a subject in itself. It reveals the promise of integration and ought to have appropriate evaluation, grading, and course marks.

\section{Objective 2: MIS in-service teacher training/professional development}

Building capacity for the Ministry of Education is considered a major part in the successful execution of the ERfKE program. MOE recognized significantly that investment in teachers is equally critical to the success of education reform as the significant investment in 
technology and e-learning resources. Accordingly new intensive professional development programs concentrated on the use and integration of technology in education. Table 2, 3 list some of the massive work done ESP in building capacity at the Ministry of Education.

Table 2. ESP Professional Development Programs Supporting ERfKE, 2004-2008

Emergency Teacher Training (2004)

New Teacher Orientation $(2005-08)$

MIS Supervisor/Teacher/Counselor Internship Program (2004)**

Instructional Strategies Training in MIS Subjects (2008 -08)

Instructional Systems Design (2006)

Communities of Practice / Champion Teacher Program (48 - Hours) (2006-08)

MIS - Outline Collaborative Teaching and Planning (2006-08 through MIS-Online)

Project-Based Learning / Buck Institute / with School-to-Career (2006)**

Support for Technology in Education / School=Based Teaching/ CADER (2005-06)

ESP Training in Mobile Technology and Classroom Management Systems (2005-06)

Technology in Education Stuudy Tour / U.S Department of State (2007)

Dokkaneh E-Commerce Application Training (2007)

Communities of Practice / Learning Teams (2006-08)

School-Based Professional Development (2008)

Support for SBPD within a School Improvement Context / School Development Units (February - May 2008)

National Conferences on School-Based Professional Development

With follow-on recommendation to be integrated into the Ministry's

New professional development framework (April 2008)

** Denotes cross-referenced with School-to-Career Program

Source: (AED, 2008) 
Table 3. YTC Professional Development Documentation

\begin{tabular}{|c|c|c|}
\hline Component & Deliverable & \\
\hline Publications & $\begin{array}{l}\text { Instructional Strategies Manual } \\
\text { Emergency Teacher Training Manual } \\
\text { Computer on Wheels Manual } \\
\text { Dokkaneh Manual and Teachers’ } \\
\text { Guides } \\
\text { Instructional Systems Design Manual } \\
\text { MIS-Online Teachers' Guide and Co- } \\
\text { Planning Templates } \\
\text { School-Based Professional } \\
\text { Development Website and Conference } \\
\text { Presentation and Workshop Materials } \\
\text { Project-Based Learning Manual } \\
\text { (Arabic) - Buck Institute }\end{array}$ & $\begin{array}{l}\text { Technology in Education Training } \\
\text { Manuals - CADER } \\
\text { Subject-Specific Training/Users' } \\
\text { Manuals - tools include Dokkaneh and } \\
\text { MIS } \\
\text { Community of Practice/Champion } \\
\text { Teachers' Manual - tools include Data- } \\
\text { Driven Decision-Making Access } \\
\text { Database } \\
\text { MIS Teachers Guides (ESP } \\
\text { Curriculum/PD) with Ramzi Ataya } \\
\text { New teacher orientation materials } \\
\text { (various) - MOE } \\
\text { School Development Unit program for } \\
\text { leadership teams - MOE }\end{array}$ \\
\hline $\begin{array}{l}\text { Studies and } \\
\text { Policy } \\
\text { Documents }\end{array}$ & $\begin{array}{l}\text { MIS Needs Assessment (2005) - Dr. } \\
\text { Omar Al-Shaykh } \\
\text { MIS Professional Development Study } \\
\text { (2008) - Razan Al-Hadidi and David } \\
\text { Balwanz } \\
\text { MIS Subject-Specific Difficulties and } \\
\text { Teacher Needs Assessment (2005) - } \\
\text { MIS Supervisors } \\
\text { Community of Practice Concept Note } \\
\text { (2006) - Dr. El Houcine Haichour } \\
\text { MIS Learning Environment and } \\
\text { Professional Development Center } \\
\text { Standards (2006) - Ministry of } \\
\text { Education Technical Committee }\end{array}$ & $\begin{array}{l}\text { School-Based Professional } \\
\text { Development Conference } \\
\text { Recommendations (2008) - SBPD } \\
\text { Conference Recommendations } \\
\text { Committee } \\
\text { General Framework for Professional } \\
\text { Development / School-Based Sections } \\
\text { (2008) - Ministry of Education } \\
\text { CADER Reports in Implementing 160- } \\
\text { Hour Professional Development } \\
\text { Program - CADER (2005-06) }\end{array}$ \\
\hline $\begin{array}{l}\text { Related } \\
\text { Training }\end{array}$ & $\begin{array}{l}\text { Economics Education TOT Training - } \\
\text { National Council for Economics } \\
\text { Education (NCEE) for two MIS } \\
\text { community leaders, MIS / ESP } \\
\text { Coordinator, Ms. Nisreen Al-Oran and } \\
\text { MIS Supervisor, Muneer Suleiman }\end{array}$ & $\begin{array}{l}\text { VB.NET Training for the Ministry/MIS } \\
\text { teachers - Microsoft (ESP-supported } \\
\text { and partially designed) }\end{array}$ \\
\hline
\end{tabular}


Source: (AED, 2008)

The interviews transcripts analyzed by applying the qualitative data analysis strategies that include three stages: (1) open coding, (2) selecting themes, (3) focused coding (Emerson et al., 1995). The analyses of the obtained information about ESP via the face-to-face interviews with ESP staff, secondary data obtained from the USAID office in Jordan, internet information, and the two focus groups that consisted of nineteen public teachers and schools principals enrolled in an international Master's Degree Program in Information and Communication Technology in Education and eighteen recent MI Stream high school graduates that were enrolled in a bachelor degree in Management Information Systems suggest that the overall performance of the YTC component was certainly sucessful and encouraging. Interviews outcomes suggest that all of the subjects, in general, expressed positive attitudes toward the modernizations of education system since the start of ERfKE and were very enthusiastic to integrate technology into the education system.

The following quotes from both focus groups support the conclusion:

Elearning curriculum elements support teaching and learning of the MIS content. It is motivating and students are more involved in the learning process (teacher1).

I wish that all other curricula desinged the same way as the MIS online curriculum (teacher2).

Access to information like teachers manuals and guides by using the internet is alot easier than before (teacher3).

Utilizing different kinds of technologies advances learning, attract student critical thinking skills (teacher4).

Elearning support a stable pedagogical method and quality instructional content for teachers and students (principal1)

Using elearning systems simplified and automated the process of students ${ }^{\text {" records }}$ (principal2).

I believe using computer advances students performance in schools (principal3).

Using elearning helped to understand things easeir without a lot of efforts (student1).

I like to learn by computers, it fun and exited (student2).

I can easily find information that I'm searching for by using computers (student3).

However, the two focus groups complained about the lack of sufficient equipments and internet services in their schools, and low salaries for teachers. The following quotes from both focus groups support that conclusion:

We don't have enough computers to meet our students' numbers and needs (teacher1).

Some of the computers we have at our computer labs are old and very slow (teacher2).

Our income is not sufficient for us to relax and be satisfied at work (teacher3). 
We are limited with budgets to fulfill our needs of technologies and improve teachers' standards of living (principal1).

I wish that I have a personal computer at school with a fast connection to the internet (student1).

We have to share one computer at school at one time (student2).

\section{Conclusions and Recommendations}

ESP successfully completed the development of 6 storylines for the MIS online program, manuals and guidebooks for the integration of economics, visual basic and teacher guides, Dokkaneh program and MIS resource library, assessment tools and methods to evaluate teacher training programs. At the end of YTC component, the Ministry of Education delivered the IT stream in 293 schools by 800 teachers serving approximately 27,000 students. Almost 2,500 teachers and 120 supervisors were trained on the content knowledge and pedagogy of the six introduced subjects under the IT stream. However, there is a strong need to increase teachers' income to help them improve their living standards.

Overall achievement of the EPS's project development objectives is indeed strong based on the substantive impact made at the educational systems in Jordan. This study and the external and internal assessments and review of supporting documents supported this claim (AED, 2008; NCHRD, 2008). However, the ERfKE program development objectives were broad and referring to a huge change in Jordan's education system and economy. Thus, it would require a long time and more comprehensive study to scientifically assess the outcomes of ERfKE. In addition, systematic monitoring and impact assessment are needed to to determine whether a change in the target areas were attributable to ERfKE or to external factors.

\section{References}

AED. (2008). Academy for Educational Development (AED). (2008, November). FINAL REPORT: EQUIP2/Jordan Education Reform for the Knowledge Economy (ERfKE) Support Project (ESP). Washington, DC.

CIA. (2009). US Central Intelligence Agency (CIA) (2009). The World Factbook: Jordan. Retrieved 25/7/2012: https://www.cia.gov/library/publications/the-world-factbook/print/jo.html

DoS. (2007). The Hashemite Kingdom of Jordan; Department of Statistics (2007). Retrieved 25/7/2012: http://www.dos.gov.jo/dos_home/dos_home_e/main/index.htm.

EHKJW. (2000). Embassy of the Hashemite Kingdom of Jordan-Washington, D.C. His Majesty King Abdullah II. "New Beginnings Making a Difference: A View from the Developing World". 25/7/2012: http://www.jordanembassyus.org/backup_now/01312000003.htm.

Encyclopedia Britannica. (2009). The Hashemite Kingdom of Jordan. Retrieved 24/7/2012: Encyclopedia Britannica Online: http://www.search.eb.com/eb/article-9106459. 
Emerson, Robert M, Rachel I. Fretz, \& Linda L. Shaw. (1995). Writing Ethnographic Fieldnotes. Chicago \& London: University of Chicago Press.

Eyango, V., \& Al-Shaer, M. (2003) USAID/Jordan: Education Assessment for Jordan 2004 2009 Country Strategy. USAID/Jordan.

GoJ. (2012). Government of Jordan; His Majesty King Abdullah II Official Website. The Education Reform for Knowledge Economy ERfKE. Retrieved 25/7/2012: http://www.kingabdullah.jo/main.php?main_page=0\&lang_hmka1=1

Intel Corporation. (2006). Embracing 21st Century Learning. Retrieved from; http://www.intel.com/go/education/

MoE. (2012). Ministry of Education; Hashemite Kingdom of Jordan. Retrieved 25/7/2012: http://www.moe.gov.jo/a_erfke/a_er.htm

NCHRD. (2008). National Center of Human Resources Development (NCHRD) (2008). "Evaluation of ICT Resources Provision, Access and Utilization” A Study Report.

NRHKJ. (2004). Ministry of Education; Hashemite Kingdom of Jordan. The Development of Education; National Report of the Hashemite Kingdom of Jordan.

NRHKJ. (2008). Ministry of Education; Hashemite Kingdom of Jordan. The Development of Education; National Report of the Hashemite Kingdom of Jordan. Retrieved 25/7/2012: http://www.ibe.unesco.org/National_Reports/ICE_2008/jordan_NR08.pdf

Toukan, K., Alnoaimi, T., \& Odibat, A. (2006)."National Education Strategy. Ministry of Education, Directorate of Education, Jordan. With Support of: CIDA and JSE.

UIS. (2007). UNESCO Institute for Statistics Jordan Country Profile, Statistics in Brief. Retrieved on 22/7/2012 from:http://stats.uis.unesco.org/unesco/TableViewer/document.aspx?ReportId=121\&IF_Lang uage $=$ eng $\& B R \_$Country $=4000$

UNDP. (2007). United Nations Development Program (UNDP). (2007). Country Fact Sheets: Jordan. $\quad$ Retrieved 25/7/2012: from: http://hdrstats.undp.org/countries/country_fact_sheets/cty_fs_JOR.html

USAID/Jordan. (2006). Strategic Statement 2007-2011(2006). Retrieved August 1, 2010 from: http://pdf.usaid.gov/pdf_docs/PDACN487.pdf.

USAID/Jordan. (2009). USAID/Jordan Strategy 2004-2009; Gateway to the Future,. Retrieved on

25/7/2012:

http://jordan.usaid.gov/upload/keydocs/2004-2009\%20USAID-Jordan\%20Strategy.pdf

USAID/Jordan. (2010). Retrieved from: http://jordan.usaid.gov/index.cfm (25/7/2012).

World Bank. (2000). Operations Evaluation Department. Partnership for Education in Jordan. Précis, No. 193. Retrieved on 22/7/2012: 


\section{Macrothink}

Journal of Management Research ISSN 1941-899X 2012, Vol. 4, No. 4

http://nweb90.worldbank.org/oed/oeddoclib.nsf/DocUNIDViewForJavaSearch/CA2A4E7A B293853C852568A8004FC84B/\$file/193precis.pdf

World Bank. (2009). World Bank 2009. Education Reform for the Knowledge Economy Project. Implementation Completion and Results Report. World Bank. Washington. DC. Retrieved 26/4/2010: http://www_wds.worldbank.org/external/default/WDSContentServer/WDSP/IB/2010/01/08/0 00334955_20100108014308/Rendered/INDEX/ICR12080P075821IC0Disclosed01161101.tx $\mathrm{t}$

\section{Acknowledgement}

A previous version of the paper was submitted to ICL2010 Conference September 15 -17, 2010 Hasselt, Belgium. 